\title{
Popper's Paradox of Democracy
}

Rijpkema, B.R.

\section{Citation}

Rijpkema, B. R. (2012). Popper's Paradox of Democracy. Think. Philosophy For Everyone, 11(32), 93-96. doi:10.1017/S147717561200019X

Version:

License:

Downloaded from: $\quad$ https://hdl.handle.net/1887/19967
Not Applicable (or Unknown)

Leiden University Non-exclusive license

Note: To cite this publication please use the final published version (if applicable). 


\section{POPPER'S PARADOX OF DEMOCRACY Bastiaan Rijpkema}

In a footnote to Chapter 7 of 'The Open Society and Its Enemies' Karl Popper describes what he calls the 'Paradox of Democracy': the possibility that a majority decides for a tyrant to rule. ${ }^{1}$ This is the lesser known paradox of the three to which he pays attention, the other two being the 'paradox of freedom' - total freedom leads to suppression of the weak by the strong - and the 'paradox of tolerance' - unlimited tolerance leads to the disappearance of tolerance.

Popper's paradoxes are of course closely related. When taken to their extremes, freedom, tolerance and democracy carry their own negation within them. Absolute freedom leads to oppression, complete tolerance to intolerance, pure democracy to tyranny. Should we then - regarding democracy simply draw the conclusion that it is in the nature of democracy that it can abolish itself? Or, as Hans Kelsen puts it: 'eine Demokratie, die sich gegen den Willen der Mehrheit zu behaupten, gar mit Gewalt sich zu behaupten versucht, hat aufgehört, Demokratie zu sein'. ${ }^{2}$

Popper is not willing to draw that conclusion, although his arguments for not doing so are rather unsatisfactory. Basically he says: there can be no democracy for the antidemocrats, just as there can be no tolerance for the intolerant and, so he reminds us: a system with some form of majority rule is the best, but not infallible, form of government control. ${ }^{3}$ Popper thus presents us with a rather pragmatic solution to the paradox of democracy: we simply need to deny anti-democrats the right to democracy for democracy to survive. This is disappointing from a rational thinker like Popper. For it seems that he does not see (or more likely: does not want to see) the seemingly iron logic 
of 'democracy as majority-rule'. The consequence of the relativism majority-rule implies, is that for democracy all beliefs and convictions are equal, so they can freely compete with each other in a Holmsian way. The theoretical Popper we know from his work in the philosophy of science seems to be replaced by a more pragmatic or utilitarian Popper when it comes to political philosophy.

The problem here is in the fact that Popper tacitly accepts that the essence of democracy - as Kelsen argues - is in majority-rule, and then argues, on grounds of desirability, that we cannot tolerate anti-democratic parties. This maneuver is understandable. When one accepts majority-rule as the defining aspect of democracy, the conclusion is inescapable:

\section{P1 Democracy is majority rule \\ P2 Anti-democratic parties can seize a majority \\ C A democracy can abolish itself}

Rather than denying the consequences afterwards, it seems prudent to take a closer look at the premises of this argument. Although the truth of the second premise seems obvious, the rightness of the first premise is less certain. Is democracy actually defined by 'majority rule'?

The Dutch constitutional scholar George van den Bergh did not think so. His 1936 inaugural lecture at the University of Amsterdam is an impassioned defense of democracy in times where the future of democracy was no longer certain. ${ }^{4}$ Van den Bergh dedicates much of his lecture to an analysis of a rather outdated Dutch law on the basis of which it would be possible to ban anti-democratic parties. $\mathrm{He}$ is, however, also concerned with the theoretical issue, in other words: the democratic paradox. Democracy, according to Van den Bergh, is not solely defined by majority-rule. Democracy is a system of self-correction. Characteristic of democracy is that it is always able to revoke its own decisions: every decision is subject to revocation. This leads Van den Bergh to conclude that all-but-one-decision 
for democracy has to be treated equally, namely: the decision to abolish democracy. The latter decision is incompatible with the nature of democracy, since the decision is irrevocable.

One could wonder, however, if this is really the sole irrevocable decision in a democracy. What to think, for instance, of a democratic decision to demolish some ageold monuments? There is, nevertheless, a subtle difference between such a decision and the decision to abolish democracy. Of course, due to factors in our outside world, the consequences of a democratic decision may be irreversible to some extent, but this does not make the decision itself irrevocable. When a democracy decides to tear down a monument and the monument is demolished accordingly, it can decide to revoke the former decision within the framework of democracy - and try to reverse the consequences, i.e. rebuild the lost monument. When, on the other hand, a democracy decides to abolish itself, the whole framework is lost, which makes the decision not only irreversible, but also irrevocable: democracy decides not to decide any more.

Van den Bergh's approach thus makes it - in contrast to Popper - also theoretically justifiable to ban antidemocratic parties. When we therefore change the first premise to 'democracy is government by self-correction', it seems quite possible to develop a coherent theory of democracy in which anti-democratic parties can be expelled from the democratic arena. It is then no longer necessary to repudiate, out of desirability, a logically compelling conclusion in retrospect.

Bastiaan Rijpkema is a PhD-Candidate at the Department of Jurisprudence, School of Law, Leiden University. b.r.rijp kema@law.leidenuniv.nl

\section{Notes}

1 The Open Society and Its Enemies (Routledge, 1995), 602-3. 
${ }^{2}$ Verteidigung der Demokratie', in: Verteidigung der Demokratie: Abhandlungen zur Demokratietheorie (Mohr Siebeck, 2006), 237.

${ }^{3}$ Popper 1995, 603.

${ }^{4}$ De democratische Staat en de niet-democratische partijen [De Arbeiderspers, 1936]; see on this in detail: Cliteur and Rijpkema, 'The Foundations of Militant Democracy', in The State of Exception and Militant Democracy in a Time of Terror, eds, Ellian and Molier, Republic of Letters, forthcoming 2012. 